\title{
INTERACTION EFFECT OF HEAT SHOCK AND SEED PRIMING ON STORABILITY OF AGROPYRON ELONGATUM
}

\author{
M. Akbarpour Bahreh ${ }^{1}$, F. Sharif Zadeh ${ }^{1}$, A. Abbasi ${ }^{1}$
}

\begin{abstract}
Priming improves germination rate and seed vigor but reduces longevity of seeds. We examined the possibilities of obatining primed seeds with maintaining high germination quality but with longevity much the same that seeds are not treated. In this study were used different priming treatments for Agropyron elongatum. Then primed seeds were placed at different levels of heat shock. And then all treatments and unprimed seeds were evaluated in standard germination and accelerated ageing test. We found that the desired longevity could be obtained by keeping the seeds under heat shock for four hours at $40^{\circ} \mathrm{C}$, after a priming treatment. Decreasing germination and seedling vigour in hydro and hormonal priming did not happaen again due to such a treatment. In addition, following priming, heat shock affects the initial quality of primed seeds in some treatments. Optimal temperature was strongly duration dependent. The method was applied to obtain primed seeds without loss of storability is very similar to those used to induce desiccation tolerance in germinated seeds and acquired thermotolerance in plant vegetative tissues.
\end{abstract}

Keywords: Heat shock; Longevity; Priming; Tall wheatgrass

\section{INTRODUCTION}

Over the past two decades, seed priming is considered as a common method in order to increase speed and uniformity of germination in the field, seedling better establishment and faster passage of environmental unfavorable conditions during germination and emergence, etc. It is used in many important crops such as wheat (Triticum aestivum), maize (Zea mays), pepper (Capsicum annuum), soybean (Glycine max) and the like for both optimal and unfavorable environmental conditions. (Iqbal \& Ashraf, 2007; Farooq et al., 2008; Korkmaz \& Korkmaz, 2009; Zhang et al., 2012). Despite the fact that priming has a large number of positive effets, when it combined with subsequent desiccation, the effect of priming is not ever positive. High germination quality is lost on desiccation, but in some situations partly retained on desiccation. However it rapidly lost in storage ( Bulter et al., 2009). Bruggink et al. (1999) were proposed and tested the hypothesis induction of longevity of primed seeds. Assuming that mechanisms conferring longevity and desiccation tolerance are related to each other, treatments that induce desiccation tolerance should also have a positive effect on longevity. They used different treatments such as heat shock (Bruggink et al., 1999). Heat shock is often defined as the rise in temperature beyond a threshold level for a period of time. In general, a transient elevation in temperature, usually $10-15^{\circ} \mathrm{C}$ above ambient temperature, is considered heat shock (Wahid et al. 2007). Seed aging is characterized by a sigmoidal relationship between viability and time (Walters et al. 2010). Accelerated ageing (AA) known as a good indicator of the storability of seed (McDonald,1999). After aging period, high vigor seeds are expected to still show high germination, whereas low vigor seeds are 
expected to show a considerable decrease in germination (Kruse, 1999; ISTA, 2010). We have described heat shock treatments that induce desiccation tolerance in primed seeds. In fact, the aims of the present study were: (1) to characterize the sensitivity of primed seeds with different substance to ageing conditions, (2) to investigate whether heat shock followed by priming induces seed longevity (3) to determine whether heat shock followed by priming can be involved in the reinforcement priming effects.

\section{MATERIALS AND METHODS}

\section{Plant Material}

Tall wheat grass (Agropyron elangatum) seeds used in this study was prepared from Bahar Researching Station of Hamedan, Iran (34 $48^{\prime}$ $\mathrm{N}-48^{\circ} 31^{\prime} \mathrm{E}$; AAP $315 \mathrm{~mm}$ ) and were kept at $3^{\circ} \mathrm{C}$ until beginning of the experiment. Seed moisture was measured by the oven method $\left(130^{\circ} \mathrm{C}\right.$ for $\left.1 \mathrm{~h}\right)$ (ISTA, 1996), before testing, which was equivalent to $7.8 \%$. In addition, a germination test was carried out to assess the initial viability at $25^{\circ} \mathrm{C}$ that showed $98 \%$ germination, the seedlings were also normal.

\section{Priming Treatments}

Priming treatments were hydropriming (seeds being exposed to distilled water for $36 \mathrm{~h}$ at $10^{\circ} \mathrm{C}$ ), osmopriming including $-0.4 \mathrm{MPa}$ for $24 \mathrm{~h}$ at $15^{\circ} \mathrm{C}$ and $-0.6 \mathrm{MPa}$ for $48 \mathrm{~h}$ at $10^{\circ} \mathrm{C}$ Urea solutions (Solution concentrations, were prepared using Van't Hoff's formula (WainTassi et al., 2012)) and hormone priming (Gibberlic acid $25 \mathrm{ppm}$ for $12 \mathrm{~h}$ at $10^{\circ} \mathrm{C}$ ). The seed subsamples were randomly selected and were placed in glass petri dishes with $15 \mathrm{~cm}$ diameter containing mentioned solutions. Solution volume in each petri was chosen based on the grounds that the seeds should not be completely submerged in the solution, i.e., on one side is almost in contact with air (In this expriment was $12 \mathrm{ml}$ ). After priming, seeds were washed several times with sterile distilled water, and then seeds surface moisture was removed with blotting paper.

\section{Accelerated Ageing Test}

At the end of imbibition, priming treatments, part of primed seeds were placed at the same temperature that were primed to reduce the moisture content to reach the surface of unprimed seeds to be ready to perform AA test. Three AA regimes were performed by suspending the primed and control seeds over $40 \mathrm{ml}$ of deionized water on a wire mesh tray in a closed plastic box $(11 \times 11 \times 4 \mathrm{~cm})$. Then the boxes were placed in the incubator with temperature of $41^{\circ} \mathrm{C}$ for 0,3 and 6 day periods (Delouche \& Baskin, 1973; ISTA, 2010). Relative humidity in the boxes was $90-95 \%$.

\section{Heat Shock After-Priming Test}

The rest of primed seeds were desiccated by means of exposing them to ambient temperature. This led to $10 \%$ decrease in moisture content (MC) (Bruggink et al. 1999). Then, seeds of each treatment separately were wrapped with foil (Al foil) (In order to avoid reduction in seed moisture). Next, seeds were placed at temperatures of 30,35 and $40^{\circ} \mathrm{C}$ for periods of one, two, three and four hours. After that, seeds were transferred to $30^{\circ} \mathrm{C}$, until the moisture content of the seeds was reached to the initial moisture level before priming (Bruggink et al. 1999). Eventually, similar to the previous section, seeds were transported to AA conditions.

\section{Germination Assays}

Samples of 300 seeds (three replicates of 100 seeds each) for each treatment were surface sterilized with $2 \%$ sodium hypochlorite for two minutes, subsequently washed with sterile distilled water before being used in the germination experiments to avoid fungus attack. Then seeds surface moisture was removed with blotting paper and were placed in petri dishes (90 $\mathrm{mm}$ diameter) with two 
moistened filter papers. Subsequently petri dishes were sealed in a nylon bag to prevent evaporation and were placed in the darkness for 21 days at a temperature $25^{\circ} \mathrm{C}( \pm 1)$ (ISTA, 1996) for evaluating germination behavior. Germinated seeds were counted daily. A seed was scored as germinated if a radical was $2 \mathrm{~mm}$ or more. The germination index (GI) was calculated as $\mathrm{GI}=\Sigma(\mathrm{Gt} / \mathrm{t})$ where $\mathrm{Gt}$ is the number of germinated seeds on day $\mathrm{t}$ (zhang et al., 2012). The seedling vigour index (SVI) was calculated as SVI $=$ Seedling length $\times$ Normal germination percentage (Abdul-Baki \& Anderson, 1973).

\section{Statistical Analysis}

Analysis of variance (ANOVA; $\mathrm{P}<0.05$ ) for comparing treatment effects in both the factorial experiment was conducted in a completely randomized design (CRD) with 3 replications. Arcsine data transformation was performed on percentage data before analysis of variance to ensure homogeneity of variance (non-transformed data appear in all tables and figures). All data were analyzed via SAS v.9.1. If the ANOVA showed significant effects, Duncan's multiple range test $(\mathrm{P}<0.05)$ was used to determine differences among treatments.

\section{RESULTS}

\section{Accelerated Ageing After Priming}

Analysis of variance of accelerated ageing after priming test showed that there is a significant difference between primed and non-primed seeds under AA $(\mathrm{P}<0.0001)$. The interaction between priming and AA were significant for all traits (Germination Percentage: F-Value $=20$. 62; $\mathrm{P}<0.0001$, Normal Seedling Percentage: F-Value $=35.66 ; \mathrm{P}<0.0001$, Seedling Vigor Index: F-Value $=28$. 97; $\mathrm{P}<$ 0.0001 and Germination Index F-Value $=$ 120.16; $\mathrm{P}<0.0001)$. It was not unexpected that with increasing age period, the percentage of germination (GP) was reduced. The GP was significantly affected by AA in primed and unprimed seeds. Under free ageing, no significant differences were observed between primed and unprimed seeds. The maximum variation in GP was illustrated for three days ageing $(\mathrm{P}<0.05)$. The highest and lowest GP allotted to hydropriming $(\mathrm{GP}=94 \%)$ and osmopriming urea $-0.4 \mathrm{MPa}(\mathrm{GP}=13.3 \%)$ respectively (Figure 01[A]). Unprimed seeds were also $69.3 \%$ germination $(\mathrm{P}<0.05)$. In six days of AA, GP in both primed and unprimed seeds was significantly declined, so that the highest GP, similar to three days of AA, was obtained for hydropriming ( $\mathrm{GP}=$ $25.3 \%)$. Although there was no significant difference with unprimed seeds $(\mathrm{GP}=18 \%)$ and osmopriming urea $-0.6 \mathrm{MPa}$ in six days of accelerated ageing was removed (Fig $01[\mathrm{~A}])$, the percentage of normal seedling (NG) was also very similar to GP (Figure1[B]). In three days of AA, the highest seedling vigor index (SVI) was devoted to hydropriming $(\mathrm{SVI}=1315)$ and unprimed seeds $(\mathrm{SVI}=875)$, respectively $(\mathrm{P}<0.05)$ (Fig 01[C]). The lowest SVI belonged to osmopriming urea $-0.4 \mathrm{MPa}$. In six days of AA, despite hydropriming maintained his supremacy, however, this superiority was not significantly different from the control (unprimed seeds). Moreover, in the course of aging, SVI values for both osmopriming was zero (Fig 01[C]). In GI similar to the previous parameters, the greatest difference between priming treatments and unprimed seeds were observed in the three days of AA. GI which is indicative of a germination rate, in hydropriming and osmopriming was the equivalent of 16.7 and 1.2, respectively (Figure 01[D]). Namely, the highest and lowest rate of germination belonged to hydropriming and osmopriming, respectively.

\section{Accelerated Ageing After Heat Shock}

Analysis of variance of accelerated ageing, followed by heat shock revealed that there is a significant difference between primed seeds exposed to different temperature and 
durations of heat shock $(\mathrm{P}<0.0001)$. The triple interactions between the priming, heat shock and AA was significant for all traits (GP: F-Value $=4.01 ; \mathrm{P}<0.0001$, SVI: F-Value $=5.22 ; \mathrm{P}<0.0001$ and GI: F-Value $=7.25 ; \mathrm{P}<$ 0.0001). Comparison of means with Duncan's multiple range test illustrated that, under free AA, priming treatments at different levels of heat shock, there was no significant difference. The greatest differences were observed in the three and six days of AA. Therefore, the results of 3 and 6 days of AA became suffice. At three days of AA, heat shock of 30 and $40^{\circ} \mathrm{C}$ in the all four-term followed by hydro and hormonal priming treatments, were higher GP (Table 01) and the lowest belonged to heat shock of $30^{\circ} \mathrm{C}$ in the all four-term followed by osmopriming urea $-6 \mathrm{MPa}$. During the six days of AA, heat shock of $40^{\circ} \mathrm{C}$ for periods 1 and 4 hours, followed by hormonal priming were the best in terms of GP. In contrast, osmopriming treatments appeared very poor so that there were no germination (Table 01). The highest
GI assigned to heat shock of $30^{\circ} \mathrm{C}$ for periods 1 and 4 hours, followed by hormonal priming and the lowest for osmopriming treatments at all levels of the heat shock in three days of AA (Table 02). In the most acute case of aging (six days), GI of all priming treatments at all levels of heat shock was dramatically decreased. According to table 2, GI equal 4.6 and 5.1 were obtained for the heat shock of $40{ }^{\circ} \mathrm{C}$ for periods 1 and 4 hours followed by hormonal priming, respectively (Table 02). Applying different levels of heat shock led to considerable variation in the amount of SVI. In three days of AA, at most levels of heat shock followed by hydro and hormonal priming, SVI was more than twice osmopriming (Table 03). Similar to previous indices at the six days of AA, the highest SVI obtained for heat shock of $40^{\circ} \mathrm{C}$ for periods 1 and 4 hours, followed by hormonal priming. Furthermore, hydropriming exposed to heat shock of 40 ${ }^{\circ} \mathrm{C}$ in all four-term had a relatively good SVI during six days of AA (Table 03).
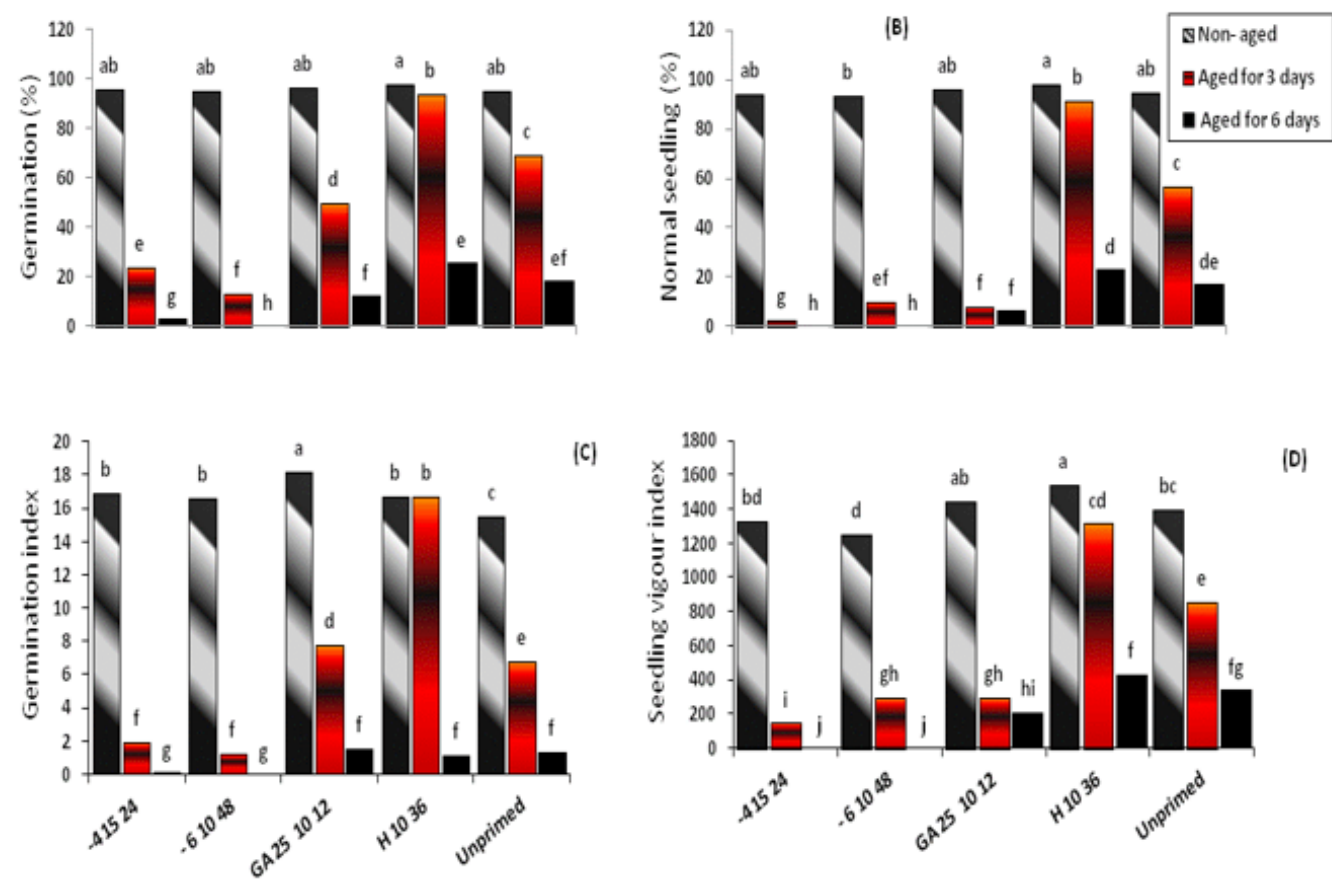

(D)

Figure 01. Germination (\%) (A), normal seedling (\%)(B), germination index (C) and seedling vigour index (D) of unprimed and primed Agropyron elongatum seeds subjected to 0,3 and 6 days accelerated aging. Priming treatments were, hydropriming for $36 \mathrm{~h}$ at $10^{\circ} \mathrm{C}$, osmopriming including $-0.4 \mathrm{MPa}$ for $24 \mathrm{~h}$ at $15^{\circ} \mathrm{C}$ and $-0.6 \mathrm{MPa}$ for $48 \mathrm{~h}$ at $10^{\circ} \mathrm{C}$ Urea solutions and hormone priming (Gibberlic acid $25 \mathrm{ppm}$ for $12 \mathrm{~h}$ at $10^{\circ} \mathrm{C}$ ). 
Table 01. Germination of Agropyron elongatum seeds at different levels of heat shock followed by priming treatments.

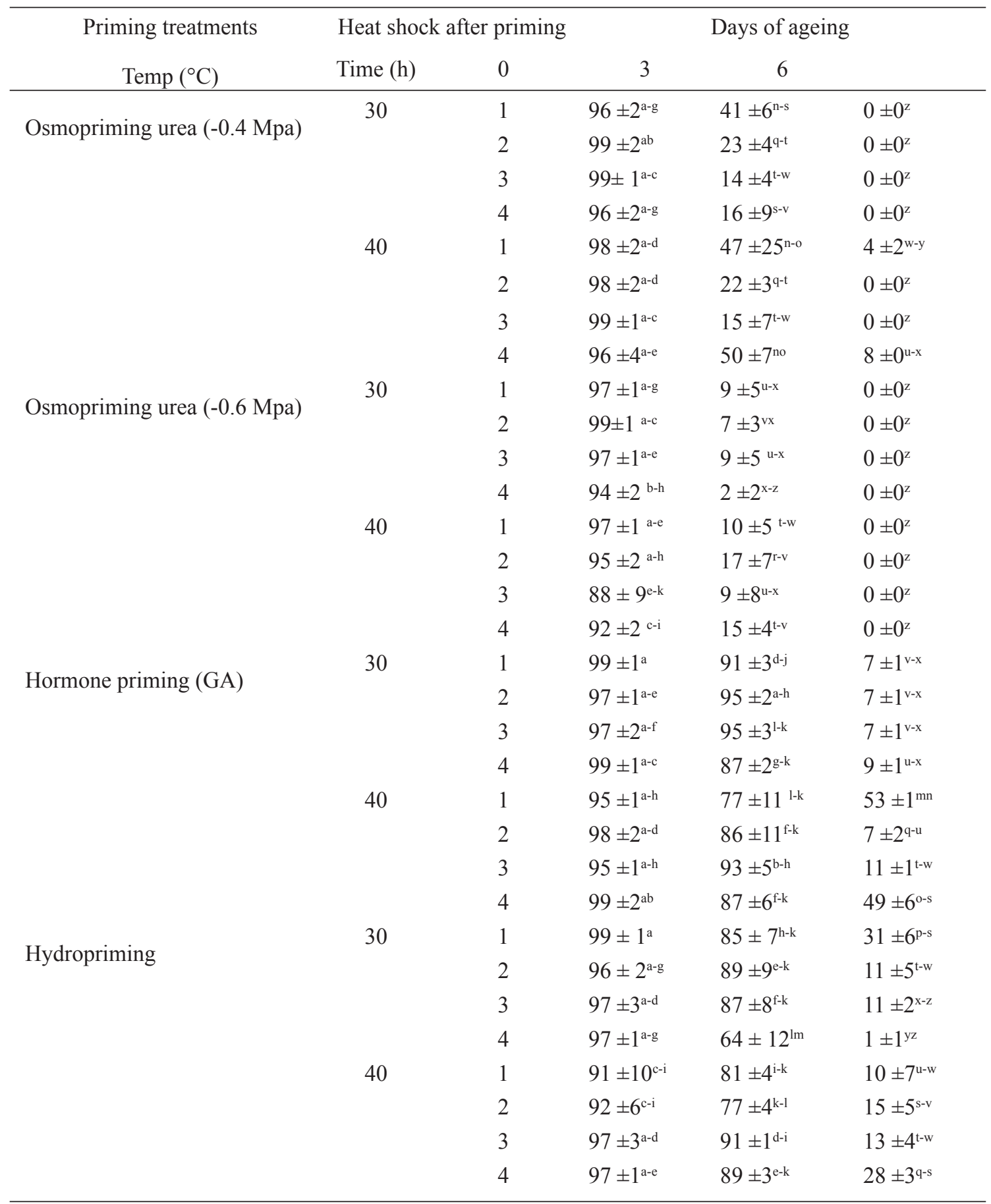

Values represent the means of three replicate .Means \pm SD without same lowercases indicate statistically significant differences for germination percentage $(\mathrm{P}<0.05)$. 
Table 02. Germination index of Agropyron elongatum seeds at different levels of heat shock followed by priming treatments.

\begin{tabular}{|c|c|c|c|c|c|}
\hline \multirow{2}{*}{$\begin{array}{l}\text { Priming treatments } \\
\text { Temp }\left({ }^{\circ} \mathrm{C}\right)\end{array}$} & \multicolumn{2}{|c|}{$\begin{array}{c}\text { Heat shock after } \\
\text { priming }\end{array}$} & \multirow[b]{2}{*}{3} & \multicolumn{2}{|c|}{ Days of ageing } \\
\hline & $\begin{array}{l}\text { Time } \\
\text { (h) }\end{array}$ & 0 & & 6 & \\
\hline \multirow[t]{8}{*}{ Osmopriming urea (-0.4 Mpa) } & 30 & 1 & $15.8 \pm 0.4^{\mathrm{JM}}$ & $4.1 \pm 0.7^{\mathrm{XZ}}$ & $0 \pm 0^{\mathrm{c}}$ \\
\hline & & 2 & $16.8 \pm 0.5^{\mathrm{GK}}$ & $1.8 \pm 0.6^{\mathrm{ac}}$ & $0 \pm 0^{c}$ \\
\hline & & 3 & $18.7 \pm 1^{\mathrm{CE}}$ & $0.8 \pm 0.2^{\mathrm{bc}}$ & $0 \pm 0^{c}$ \\
\hline & & 4 & $18.3 \pm 0.5^{\mathrm{CH}}$ & $1.1 \pm 0.6^{\mathrm{bc}}$ & $0 \pm 0^{\mathrm{c}}$ \\
\hline & 40 & 1 & $17 \pm 0.4^{\mathrm{FJ}}$ & $3.3 \pm 1.8^{\mathrm{Ya}}$ & $0 \pm 0.1^{\mathrm{c}}$ \\
\hline & & 2 & $16.8 \pm 0.6^{\mathrm{HL}}$ & $1.5 \pm 0.3^{\mathrm{bc}}$ & $0 \pm 0^{c}$ \\
\hline & & 3 & $17.1 \pm 1.1^{\mathrm{EJ}}$ & $0.7 \pm 0.5^{\mathrm{bc}}$ & $0 \pm 0^{\mathrm{c}}$ \\
\hline & & 4 & $15.9 \pm 0.8^{\mathrm{JM}}$ & $3 \pm 0.9^{\mathrm{Za}}$ & $0.6 \pm 0^{\mathrm{bc}}$ \\
\hline \multirow[t]{8}{*}{ Osmopriming urea (-0.6 Mpa) } & 30 & 1 & $15.6 \pm 1.1^{\mathrm{JN}}$ & $0.6 \pm 0.2^{\mathrm{bc}}$ & $0 \pm 0^{c}$ \\
\hline & & 2 & $18.5 \pm 1^{\mathrm{CG}}$ & $0.3 \pm 0.4^{\mathrm{bc}}$ & $0 \pm 0^{c}$ \\
\hline & & 3 & $16.7 \pm 0.4^{\mathrm{IL}}$ & $0.6 \pm 0.2^{\mathrm{bc}}$ & $0 \pm 0^{c}$ \\
\hline & & 4 & $15.9 \pm 1.2^{\mathrm{JM}}$ & $0.1 \pm 0.1^{\mathrm{bc}}$ & $0 \pm 0^{c}$ \\
\hline & 40 & 1 & $15.2 \pm 0.8^{\mathrm{KP}}$ & $0.6 \pm 0.4^{\mathrm{bc}}$ & $0 \pm 0^{c}$ \\
\hline & & 2 & $15.1 \pm 1.1^{\mathrm{LP}}$ & $1.4 \pm 1^{\mathrm{bc}}$ & $0 \pm 0^{\mathrm{c}}$ \\
\hline & & 3 & $13.5 \pm 1.1^{\mathrm{QT}}$ & $0.5 \pm 0.7^{\mathrm{bc}}$ & $0 \pm 0^{c}$ \\
\hline & & 4 & $12.3 \pm 0.9^{\mathrm{TV}}$ & $0.9 \pm 0.3^{\mathrm{bc}}$ & $0 \pm 0^{c}$ \\
\hline \multirow[t]{8}{*}{ Hormone priming (GA) } & 30 & 1 & $18.9 \pm 1.3^{\mathrm{BD}}$ & $18.4 \pm 0.5^{\mathrm{CG}}$ & $0.6 \pm 0^{\mathrm{bc}}$ \\
\hline & & 2 & $20.4 \pm 0.8^{\mathrm{AB}}$ & $19.1 \pm 0.9^{\mathrm{BD}}$ & $0.7 \pm 0.1^{\mathrm{bc}}$ \\
\hline & & 3 & $19.5 \pm 0.9^{\mathrm{BC}}$ & $14.8 \pm 1.1^{\mathrm{MQ}}$ & $0.7 \pm 0.2^{\mathrm{bc}}$ \\
\hline & & 4 & $21 \pm 0.2^{\mathrm{A}}$ & $18.4 \pm 1.3^{\mathrm{CH}}$ & $0.8 \pm 0^{\mathrm{bc}}$ \\
\hline & 40 & 1 & $18.5 \pm 0.8^{\mathrm{CF}}$ & $11.8 \pm 2.5^{\mathrm{UV}}$ & $4.6 \pm 1.4^{X Y}$ \\
\hline & & 2 & $19 \pm 0.8^{\mathrm{BD}}$ & $16 \pm 3^{\mathrm{JM}}$ & $0.7 \pm 0.1^{\mathrm{bc}}$ \\
\hline & & 3 & $18.5 \pm 0.2^{\mathrm{CF}}$ & $17.2 \pm 1.1^{\mathrm{EJ}}$ & $0.9 \pm 0.2^{\mathrm{bc}}$ \\
\hline & & 4 & $19.2 \pm 0.7^{\mathrm{BD}}$ & $14.7 \pm 0.5^{\mathrm{MQ}}$ & $5.1 \pm 0.4^{\mathrm{X}}$ \\
\hline \multirow[t]{8}{*}{ Hydropriming } & 30 & 1 & $16.8 \pm 1.5^{\mathrm{GK}}$ & $13.9 \pm 1.2^{\mathrm{OT}}$ & $1.8 \pm 0.4^{\mathrm{bc}}$ \\
\hline & & 2 & $15.3 \pm 1.2^{\mathrm{KO}}$ & $13 \pm 0.4^{\mathrm{RT}}$ & $0.8 \pm 0.2^{\mathrm{bc}}$ \\
\hline & & 3 & $17.7 \pm 1.4^{\mathrm{DI}}$ & $14.6 \pm 1.8^{\mathrm{MR}}$ & $0.1 \pm 0.1^{\mathrm{bc}}$ \\
\hline & & 4 & $16.7 \pm 1.4^{\mathrm{IL}}$ & $9.6 \pm 1.9^{\mathrm{W}}$ & $0 \pm 0.1^{\mathrm{c}}$ \\
\hline & 40 & 1 & $14.1 \pm 1.6^{\mathrm{NS}}$ & $11.3 \pm 0.6^{\mathrm{V}}$ & $0.6 \pm 0.5^{\mathrm{bc}}$ \\
\hline & & 2 & $12.9 \pm 0.7^{\mathrm{sU}}$ & $12.5 \pm 0.8^{\mathrm{TV}}$ & $1 \pm 0.4^{\mathrm{bc}}$ \\
\hline & & 3 & $16.6 \pm 0.3^{\mathrm{IL}}$ & $14.9 \pm 0.7^{\mathrm{MQ}}$ & $0.9 \pm 0.2^{\mathrm{bc}}$ \\
\hline & & 4 & $15.9 \pm 1.5^{\mathrm{JM}}$ & $13.6 \pm 0.9^{\mathrm{PT}}$ & $1.8 \pm 0.1^{\mathrm{bc}}$ \\
\hline
\end{tabular}

Values represent the means of three replicate. Means \pm SD without same lowercases indicate statistically significant differences for germination index $(\mathrm{P}<0.05)$. 
Table 03. Seedling vigour index of Agropyron elongatum seeds at different levels of heat shock followed by priming treatments.

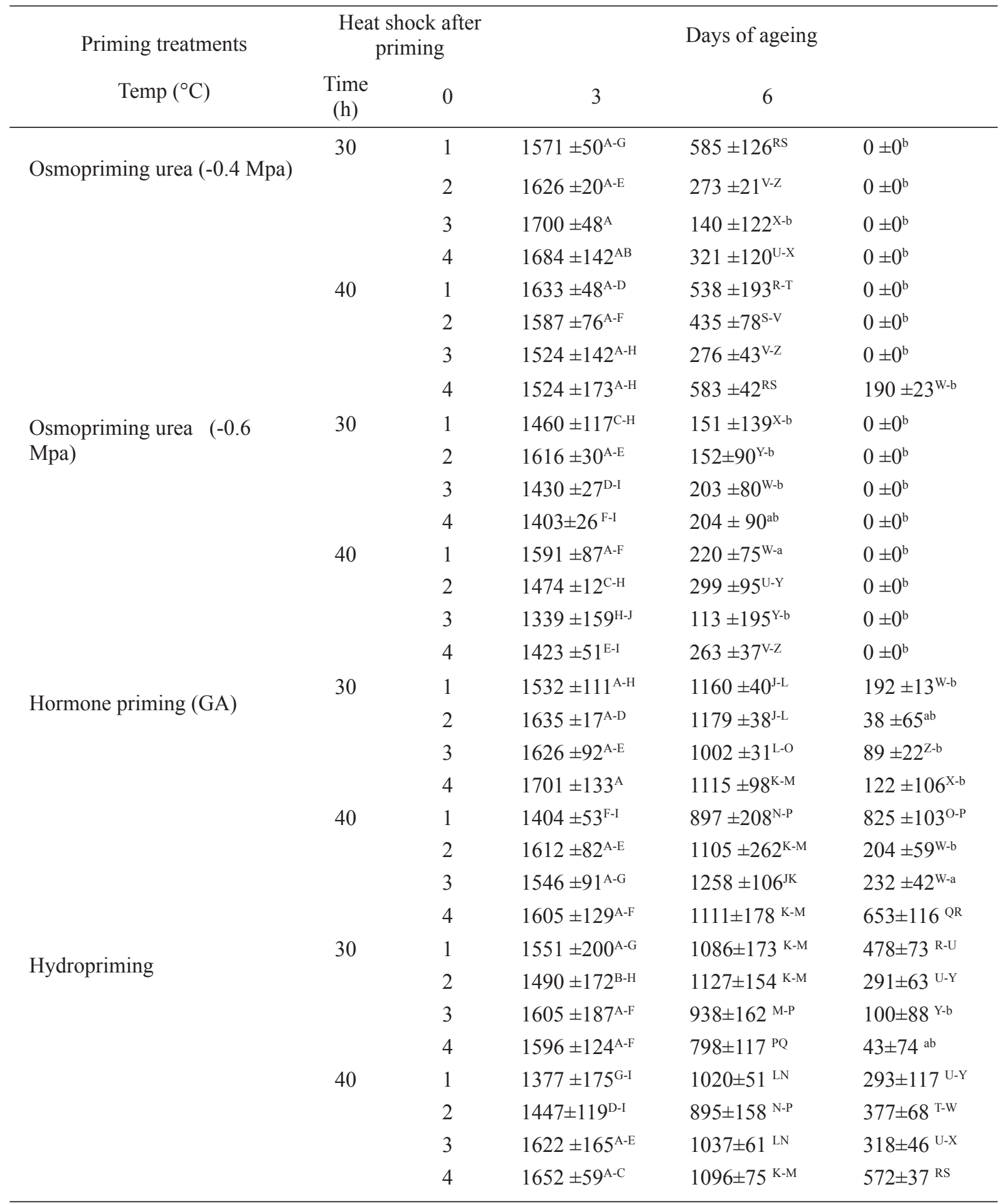

Values represent the means of three replicate. Means \pm SD without same lowercases indicate statistically significant differences for seedling vigour index $(\mathrm{P}<0.05)$. 


\section{DISCUSSION}

The responce of unshocked and heat shocked priming treatments to be defferent to AA. Although the comparison between unshocked and shocked priming treatments not performed, with a glimpse of the data, can be found that in three days of the AA at all levels of heat shock followed by hormonal priming, GP (With an average of $89 \%$ ) (Table 01) significantly increased compared to the situation without heat shock $(\mathrm{GP}=50)$. While unprimed seeds had 69\% GP (Fig 01[A]). By applying heat shock of $40^{\circ} \mathrm{C}$ for periods 1 and 4 hours and $30^{\circ} \mathrm{C}$ for 1 hour, followed by osmopriming urea $-0.4 \mathrm{MPa}$, GP was about 50 percent (Table 01; Three-days AA), whereas in the unshocked was 24\% (Fig 01[A]). At six days of the AA, unshocked and shoked osmopriming treatments cannot endure. This information suggests that many factors can be effective in inducing storability of primed seeds and in fact, in maintaining the desirable properties of priming. Type of material, temperature and duration of priming, and also temperature and duration of heat shock, were all involved in providing different responses. However, most aging studies have been conducted on primed seeds with different Materials and Methods, have revealed that priming often reduces seed longevity (Bruggink et al. 1999; Gurusinghe \& Bradford, 2001, Lin et al. 2005). This study was also no exception to this rule. During the last decade, some investigators were trying to use different post-priming methods, to return the longevity of primed seeds. In study of Bruggink et al.(1999), PEG incubation of primed seeds for 3 days and heat shock (40 $\left.{ }^{\circ} \mathrm{C}\right)$ treatment of $3 \mathrm{~h}$ were able to prevent the reduction in longevity. Lin et al. (2005) concluded that while slow drying improved the initial quality of primed seeds, In contrast, fast drying led to a rapid reduction of seed longevity in storage. In their study, slow-dried seeds initially accumulated less amounts of MDA and total peroxide as compared to fastdried seeds. The results obtained from our study are interesting to note. As mentioned in results, after three days of AA, the SVI of 294 was obtained for unshocked gibberlic acid (GA) priming. But when used the shock of $40{ }^{\circ} \mathrm{C}$ for $3 \mathrm{~h}$, SVI increased to 1258 . A threefold increase is unique in its kind. It was even more the control (SVI=857). The similarity in inductive methods for desiccation tolerance in germinated seeds and for storability in primed seeds suggests that the same physiological mechanisms are involved (Bruggink et al.1999). Desiccation tolerance of seeds is a complex multifactorial trait involving a multitude of genes whose expression ultimately leads to mechanisms of both cellular protection and cellular repair (Gallardo et al., 2001). Tikhomirova (1985) expressed that in Pennisetum glaucum, presowing hardening of the seed at $42{ }^{\circ} \mathrm{C}$ resulted in plants tolerant to overheating and dehydration and showing higher levels of water-soluble proteins and lower amounts of amide- $\mathrm{N}$ in leaves compared to non-hardened plants. In the process of heat acclimatization, heat shock factors (Hsfs) play an important role in regulation of this heatinduced transcriptional reprogramming (Kotak et al., 2007). Immediately after exposure to heat shocks and perception of signals, changes occur at the molecular level altering the expression of genes and accumulation of transcripts, therefore leading to the synthesis of stress induced proteins as a heat-tolerance strategy (lba, 2002). The production of heat shock proteins (HSPs) is known to be a significant adaptive strategy in this regard. The HSPs have chaperone-like functions and are involved in signal transduction during heat shock (Wahid et al., 2007). Additionally, there are late embryogenesis abundant (LEA) like proteins genes that are induced in vegetative tissues in response to high temperatures, drought and salinity stress or by exogenous ABA (Tunnadiffe \& Wise.2007; Bies-Etheve et al. 2008). Other studies (Larkindale \& Knight, 2002 and Larkindale et al. 2005) shed some light on crosstalk between the hormonal, 
redox and calcium-activated signalling pathways which can play a role in heattolerance to ensure a rapid response which is essential for survival against heat shock. During recent years there has been increasing evidence on the role of Salicylic acid (SA) in acquiring of tolerance mechanism in several abiotic stress conditions (Horvath et al., 2007). It has also been suggested SA to be involved in heat-shock responses ( Liu et al., 2006). In report of Alonso-Ramirez et al. (2009) became clear that the overexpression of a FsGASA4 (gene from Fagus sylvatica) in Arabidopsis improves plant tolerance to heat shock, through an increase in SA biosynthesis. On the other hand, overexpression of FsGASA4 in Arabidopsis induces high tolerance to paclobutrazol (GA biosynthesis inhibitor) and reduces the dependence of GA for growing (Alonso-Ramirez et al., 2009). Heckman et al.( 2002) pointed that Kentucky bluegrass (Poa pratensis) plants treated with a GA inhibitor were less heat tolerant than untreated plants. In addition, the overexpression of a GASA4 in Arabidopsis induces resistance to heat shock (Ko et al., 2007). In report of Alonso-Ramirez et al.(2009) the exogenous application of GA3 was able to revert the inhibitory effect of heat stress in Arabidopsis seedlings. Findings of current study are consistent with those of Alonso-Ramirez et al (2009). At six days of the AA, by the applying of heat shock at $40^{\circ} \mathrm{C}$ for 1 and 4 hours after GA priming, GP obtained 59 and $49 \%$, respectively (Table 01 ). Whereas in the unshocked and unprimed germination was 12 and $18 \%$, respectively (Fig 01[A]). The results reinforce the role of GAs in the acquisition of thermotolerance. The most interesting data in study of Alonso-Ramirez et al.(2009) was the 2-fold concentration of SA detected in transgenic seeds (containing GASA4) compared with wild-type seeds. Additionally, they confirmed that exogenous SA was able to revert to the inhibitory effect of salt, oxidative, and heat stress in seed germination. The results suggesting that GAs are involved in plant responses to abiotic stress by modulating SA levels. It has been proved that SA is an effective compound against oxidative damage, by increasing antioxidant capacity reduces lipid peroxidation (Ananieva et al., 2002, 2004). Induction and reinforcement of the antioxidant systems is influenced by SA and thereby causes the protection from oxidative damage under heat shock (Hayat \& Ahmad, 2007). Clarke et al.(2009) demonstrated that SA and jasmonic acid (JA) both act to confer thermotolerance; however, in their experimental approach, ethylene (ET) acts to increase heat shock-associated cell death. These authors for the acquired thermotolerance assay, Petri dishes containing 3 -wk-old plants (Arabidopsis thaliana) grown on MS medium were exposed to a $2 \mathrm{~h} 45^{\circ} \mathrm{C}$. Nevertheless, information about the onset of tolerance mechanisms mediated by SA at the level of seed is very scarce. In addition, Larkindale et al. (2005) observed an increase in the level of absicic acid (ABA) upon recovery from heat shock suggesting a role at the latter period. ABA is inductor of acclimation/adaptation in plants to desiccation by modulating the up- or down-regulation of abundant genes (Xiang et al., 2002). These approaches reflect a complex cross-talk among different hormones at both levels biosynthesis and action (Weiss \& Ori, 2007). There are specified LEA genes that are induced in vegetative tissues in response to high temperatures, drought, salinity stress or by exogenous ABA (Tunnadiffe \& Wise.2007; Bies-Etheve et al., 2008).

\section{CONCLUSIONS}

In conclusion, the results described here reconfirm that priming improves the initial quality of Tall wheatgrass seeds. The method of heat shock following priming also affects the initial quality of primed seeds. As mentioned above, the shock of $40^{\circ} \mathrm{C}$ for 1 and $4 \mathrm{~h}$ was able to improve longevity in primed seeds with GA. Although we could not investigate molecular dimensions of these treatments, the similarity in induction methods for heat tolerance in 
germinated seeds (or different plant organs) and for longevity in primed seeds suggests that the same physiological mechanisms are involved. Future researches with more focus on validating heat shock effects on storability of primed seeds are therefore suggested. By studying of the physiological and molecular mechanisms involved in these processes, a large number of questions can be answered in this case.

\section{REFERENCES}

Abdul -Baki, A.A., and J.D., Anderson, 1973. Vigor determination in soybean by multiple criteria. Crop Sci., 13: 630-633.

Alonso-Ramirez, A., Rodriguez , D., Reyes D., Jimenez J.A., Nicolas, G., Lopez-Climent, M., Gomez-Cadenas, A. and Nicolas, C. 2009. Evidence for a Role of Gibberellins in Salicylic Acid-Modulated Early Plant Responses to Abiotic Stress in Arabidopsis Seeds. Plant Physiology.150: 1335-1344.

Ananieva EA, Alexieva VS, Popova LP (2002) Treatment with salicylic acid decreases the effects of paraquat on photosynthesis. J Plant Physiol 159: 685-693.

Ananieva EA, Christov KN, Popova LP (2004) Exogenous treatment with salicylic acid leads to increased antioxidant capacity in leaves of barley plants exposed to paraquat. J Plant Physiol 161: 319-328.

Bies-Etheve, N., Gaubier-Comella, P., Debures, A., Lasserre. E., jobet. E..Raynal. M., Cooke.R., Delseny,M. 2008. Inventory,evolution and expression profiling diversity of the LEA (Late embryogenesis abundant) protein gene family in Arabidopsis thaliana. Plant Mol. Biol. 67, 107-124.

Bruggink, G.T., Ooms, J.J.J., Van der Toorn, P., 1999. Induction of longevity in primed seeds. Seed Sci. Res. 9, 49-53.

Butler, L.H., Hay,F.R., Ellis R.H., Smith,R.D., Murray, T.B. 2009. Priming and re-drying improve the survival of mature seeds of Digitalis purpurea during storage, Ann. Bot. 103 $1261-1270$.

Delouche JC, Baskin CC. 1973. Accelerated ageing techniques for predicting the relative storability of seed lots. Seed Science and Technology 1, 427-52.

Farooq, M., T. Aziz, S.M.A.Basra, M.A. Cheema, and H. Rehman. 2008. Chilling tolerance in hybrid maize induced by seed priming with salicylic acid. Journal Agronomy \& Crop Science194:161-168.

Gallardo K, Job C, Groot SPC, Puype M, Demol H, Vandekerckhove J, Job D (2001) Proteomic analysis of Arabidopsis seed germination and priming. Plant Physiol 126: 835-848.

Gurusinghe S. and Bradford K.J. 2001.Galactosyl-sucrose oligosaccharides and potential longevity of primed seeds. Seed Science Research 11: 121-133.

Hayat, S.; Ahmad, A. Salicylic Acid: A Plant Hormone. Netherlands: Springer, 2007, PP. 100103. 
Heckman NL, Horst GL, Gaussoin RE, Tavener BT (2002) Trinexapacethyl influence on cell membrane thermostability of Kentucky bluegrass leaf tissue. Sci Hortic (Amsterdam) 92: $183-186$.

Horvath E, Szalai G, Janda T (2007) Induction of abiotic stress tolerance by salicylic acid signaling. J Plant Growth Regul 26: 290-300.

Iba, K., 2002. Acclimative response to temperature stress in higher plants: approaches of gene engineering for temperature tolerance. Annu. Rev. Plant Biol. 53, 225-245.

Iqbal, M. and M. Ashraf. 2007. Seed preconditioning modulates growth, ionic relations, and photosynthetic capacity in adult plants of hexaploid wheat under salt stress. Journal of Plant Nutrition. 30:381-396.

ISTA., 1996. Rules for Seed Testing. International Seed Testing Association (ISTA), Zurich, Switzerland.

ISTA., 2010. International Rules for Seed Testing, International Seed Testing Association (ISTA), Zurich, Switzerland.

Ko CB, Woo YM, Lee DJ, Lee MC, Kim CS (2007) Enhanced tolerance to heat stress in transgenic plants expressing the GASA4 gene. Plant Physiol Biochem 45: 722-728.

Korkmaz, A. andY. Korkmaz. 2009. Promotion by 5-aminolevulenic acid of pepper seed germination and seedling emergence under low-temperature stress. Scientia Horticulturae. 119:98-102.

Kotak S, Larkindale J, Lee U, von Koskull-Döring P, Vierling E, Scharf KD. 2007. Complexity of the heat stress response in plants. Current Opinion in Plant Biology 10, 310-316.

Kruse, M. 1999. Application of the normal distribution for testing the potential of the controlled deterioration test. Crop Science 39, 1125-1129.

Larkindale, J., and Knight, M. R., 2002. Protection against heat stress-induced oxidative damage in arabidopsis involves calcium, abscisic acid, ethylene, and salicylic acid. PlantPhysiol., 128: $682-695$.

Larkindale, J., Hall, J. D., Knight, M. R., and Vierling, E., 2005. Heat stress phenotypes of arabidopsis mutants implicate multiple signaling pathways in the acquisition of thermotolerance. Plant Physiol., 138: 882-897.

Lin R.H., Chen K.Y., Chen C.L., Chen J.J.,. Sung J.M. 2005. Slow post-hydration drying improves initial quality but reduces longevity of primed bitter gourd seeds. Scientia Horticulturae 106: 114-124.

Liu, H-T.; Liu, Y-Y.; Pan, Q-H.; Yang H-R. Zhan Ji-CH.; and Huang, W-D. 2006. Novel interrelationship between salicylic acid, abscisic acid, and PIP2-specific phospholipase $\mathrm{C}$ in heat acclimation-induced thermotolerance in pea leaves. Journal of Experimental Botany. 57: 3337-3347. 
McDonald, M.B. 1999. Seed deterioration: physiology, repair and assessment, Seed Sci. Technol. 27: 177-237.

Tikhomirova, E.V. 1985. Changes of nitrogen metabolism in millet at elevated temperatures.. Field Crops Research, 11: 259-264.

Tunnacliffe, A., Wise, MJ., 2007.The continuing conundrum of LFA proteins. Naturwissenschaften $94,791-812$.

Wahid, A., Gelani, S., Ashraf, M., \& Foolad,M.R. 2007. Heat tolerance in plants: an overview. Environmental and Experimental Botany. 61: 199-223.

Wain-Tassi A. L, Santos J. F.D, Panizzi R. D. C, Vieira R D., 2012. Seed-borne pathogens and electrical conductivity of soybean seeds. Scientia Agricola. 69: 19-25.

Walters, Ch., Ballesteros, D., Vertucci, V. A. 2010. Structural mechanics of seed deterioration: Standing the test of time. Plant Science 179: 565-573.

Weiss D, Ori N. 2007. Mechanisms of cross talk between gibberellin and other hormones. Plant Physiol 144: 1240-1246.

Xiong, L., Lee, H., Ishitani, M., Zhu, J.-K. 2002. Regulation of osmotic stress responsive gene expression by LOS6/ABA1 locus in Arabidopsis. J. Bioi. Chern. 277, 8588-8596.

Zhang M, Wang Z, Yuan L, Yin C, Cheng J, Wang L, Huang J and Zhang H, 2012.Osmopriming improves tomato seed vigor under aging and salinity stress. African Journal of Biotechnology 11: 6305-6311. 